\title{
TÕDE, IDENTITEET JA MORAALNE ABSOLUUT
}

\author{
MARTIN EHALA
}

$\mathrm{V}$ iimase kümmekonna aasta jooksul on tõde nagu liiv näppude vahelt maha jooksnud: oleme jõudnud tõejärgsesse või täpsemalt öeldes faktijärgsesse ühiskonda, mida iseloomustab asjaolu, et fakt kui argument on kaotanud poliitilistes ja ideoloogilistes aruteludes oma veenmisjõu (vt AriasMaldonado 2018). Fakt on väide, mida usutakse olevat tõene. See kaotab veenmisjõu, kui on piisavalt inimesi, kes selle tõesuses kahtleb. Tõejärgsus on niisiis tõe hegemoonia murenemise tagajärg.

Osaliselt on olukorra eest vastutavad humanitaarteadlased, esmalt analüütilise filosoofia esindajad ja nende tuules postmodernistid teistes pehmetes teadustes. Artikli algul toongi esile hästi tuntud erinevuse loodusteaduslike ja humanitaarteaduslike tõdede vahel, mis on viimase saja või enama aasta jooksul põhjustanud tõsise tõeskeptitsismi. Ühena esimestest argumenteeris Gottlob Frege XIX sajandi lõpul, et tõde kui sellist ei ole olemas (vt Stoljar, Damnjanovic 2014). Umbes samal ajal näitas George Moore (1903), et kesksetel moraalimõistetel, nagu hea ja kuri, puudub sisu. Mõnevõrra hiljem arendas Ludwig Wittgenstein (2005 [1953]) välja idee keelemängust, millega ta kritiseeris asja ja mõiste omavahelist vastavust, haakides niimoodi keele lahti reaalsusest. Viimane oli Jean-François Lyotardile (1984 [1979]) postmodernismi aluste sõnastamise otseseks tõukeks. Seejärel pääses kõik nagu paisu tagant: Foucault, Derrida, Rorty, kui nimetada mõnd mõjukamat teerajajat maailmavaates, mis sajandivahetuseks oli juba sügavalt mõjutanud lääne heaoluühiskondi.

Tänapäeval on tõe sotsiaalse konstrueerituse idee muutunud ühiskondlikes aruteludes üldaktsepteerituks. See aga tähendab, et igasugune tõde on seotud identiteediga, see on etnotsentriline, kuna põhineb mingi ühiskonna või kultuurilise rühma konsensusel. Ja sedavõrd, kuidas infotehnoloogia areng on kaasa toonud auditooriumi killustumise, on suured rahvusidentiteedid hakanud lagunema väikesteks kogukondadeks. Igaühel neist väikestest identiteetidest on omad tuumväärtused, mida nad hindavad ja mis neid koos hoiavad. Selle põhjal püüan esile tuua tõe ja identiteedi paradoksaalse seose: tõe hegemoonia on oluline kollektiivse identiteedi kestlikkusele, samal ajal näib see eeldavat tõe relatiivsuse tunnistamist, kuivõrd eri identiteetidel on erinevad tuumväärtused.

Tõe hegemoonia murenemine rahvusjärgses ühiskonnas on humanitaarteadustele ja teadusele laiemaltki eksistentsiaalne küsimus, sest kui leppida asjaoluga, et tõde on identiteedipõhine, siis tuleb leppida ka mis tahes alternatiivsete faktidega ja erinevate seletustega Maa kuju kohta, mis eri identiteediga rühmades on omaks võetud. Ma ei näe sellest ummikseisust muud väljapääsu kui tunnistada ühe absoluutse ehk jumaliku tõe olemasolu niihästi maailma olemuse kui ka inimeseks olemise kohta, olgugi et seda tõde ei ole 
lõpuni suudetud tunnetada. Artikli teises pooles toon esile, kuidas see idee on leidnud väljenduse näiteks Konfutsiuse ja Immanuel Kanti õpetuses.

Isegi kui uskuda absoluudi olemasolu, jääb küsimus, kuidas seda tunnetada. Nii Konfutsius kui ka Kant viitavad intuitsioonile, aga õhku jääb küsimus, kuidas võrrelda ja hinnata eri mõtlejate intuitsiooni vilju. Kuidas me end humanitaarteadlastena ka ei positsioneeriks, on meie uurimistulemustel mõju tuumväärtustele, mis võib viia ja sageli ongi viinud moraalisüsteemi muutumiseni. Kas see on vaid ühtede tõdede vaheldumine teistega või viib moraalse absoluudi üha täielikuma tunnetamiseni? Artikli viimane osa püüab vastust leida, kas on võimalik ette kujutada mingit metodoloogiat, millega hinnata humanitaarteaduslike tõdede, eeskätt just väärtuste ja moraalinormide kohta käivate väidete tõepärasust, st vastavust moraalse absoluudiga. Ja mu vastus on jaatav.

\section{Loodusteaduslik ja humanitaarteaduslik tõde}

Lääne ühiskonnas välja arendatud loodusteaduslik meetod lähtub eeldusest, et tõde on olemas ja seda on võimalik süstemaatilise uurimisega välja selgitada. Selle meetodi raames on kokku lepitud mõningates põhimõtetes, mille alusel väidete ja seletuste paikapidavuse üle otsustada. Üks neist on Occami habemenuga, mille kohaselt nähtuse kahest võrdselt heast seletusest tuleks tõeseks pidada lihtsamat. Teine oluline põhimõte on kummutatavus: teadusliku tõena ei saa võtta ühtegi väidet ega seletust, mida pole võimalik ümber lükata, mistõttu iga kehtiv tõde on vaid hüpotees, mida pole seni õnnestunud ümber lükata (Popper 1959).

Seega on alternatiivsed seletused ja isegi alternatiivsed faktid ka loodusteaduses igapäevane nähtus, aga loodusteaduslik meetod põhineb siiski eeldusel, et üks mitmest seletusest või mõõtmistulemusest on tõene, kuni seda pole ümber lükatud mõne uue avastuse või täpsema mõõtmisega. Ja kui alternatiivide vahel pole võimalik valida, siis uuritakse ja vaieldakse seni, kuni selgus käes. Humanitaar- ja ühiskonnateadustes on olukord keerulisem kas seetõttu, et alternatiivsed seletused lähtuvad erinevatest eeldustest, mille tõesuse kontrollimine jääb väljapoole meie tunnetuse piire, või siis ei ole väited empiiriliselt kontrollitavad, sest need puudutavad ühiskondlikke norme või tähendusi. Näiteks ei ole võimalik eesti keele grammatika reeglit, et sõna lammas omastava käände vorm on lamba (nagu ilmneb lauses Juhan veristas lamba), kummutada näitega, et käesolevas artiklis seisab mustvalgel: Juhan veristas lammase. Sellegipoolest püütakse ka pehmetes teadustes sama teoreetilise raamistiku piires teadusliku argumentatsiooni abil jõuda seletuste ja faktide tõe osas konsensusele.

Samas on humanitaarteadustes kindlasti uurimisvaldkondi, kus konsensuse saavutamine pole tõenäoline, sest erinevad teooriad ja seletused kajastavad alternatiivseid vaatepunkte, mis on seotud eri kultuuriliste identiteetidega, mille väärtustest lähtudes need tõed on tunnetatud. Ja kuna pole võimalik nimetada osa identiteete vääraks, pole võimalik ka väita, et mõni identiteedipõhistest seletustest oleks tõene ja teised väärad. See puudutab eeskätt ajaloolist tõde, mis otseselt sõltub identiteedipõhistest väärtushinnangutest ja 
sellest, mida üks või teine kultuur nähtusena käsitleb, millest mööda vaatab või mille maha vaikib. Seetõttu on kõik sellised tõed etnotsentrilised mõiste laias tähenduses, st mitte üksnes etnilise, vaid mis tahes kultuurilise identiteedi kesksed.

\section{Tõe etnotsentrilisus}

Seega on tõe etnotsentrilisus humanitaarteaduste põhiline eripära võrreldes loodusteadustega. Ja sedavõrd, kuidas maailm on muutunud väiksemaks ning teadmised kultuurilise mitmekesisuse kohta valdavamaks, on arusaam humanitaarteaduslike tõdede suhtelisusest XX sajandil üha tugevnenud. Kui kunsti jt kultuurinähtuste mitmekesisust saab pidada rikkuseks, siis moraalinormide mitmekesisus nõuab seletust.

John Mackie (1977) pakub oma moraali eksitusteoorias (ingl moral error theory) välja kaks seletust. Esiteks, inimesed ei suuda fundamentaalseid moraalitõdesid ühtmoodi tajuda, st erinevused tulenevad moraali ainese ebapiisavast tundmisest. Seega on vaidlus moraalitõdede üle sama nagu loodusteaduslik vaidlus maailma olemuse üle. Teine seletus on see, et mingit moraalset absoluuti ei eksisteerigi ja inimesed konstrueerivad moraalitõed selleks, et õigustada eluviisi, mida nad nii ehk teisiti praktiseerivad. Näiteks, kui mõni ei salli homosid, siis tahaks ta moraalireeglit, et neid võib kividega surnuks loopida. Ja kui selliseid on palju, siis selline reegel kehtestataksegi.

Neid kaht seletust analüüsides jõuab Mackie (1977) Occami habemenuga rakendades järeldusele, et teine seletus on parem, sest põhineb selgetel ja teada-tuntud faktidel: inimeste elustiilid on äärmiselt mitmekesised ja inimestel on kalduvus uskuda seda, mida neil on kasulik uskuda. Neist kahest eeldusest tulenevadki vasturääkivad moraalitõed. Esimene seletus nõuaks aga keerukat filosoofilist põhjendust, miks inimesed ei suuda moraalset absoluuti ühtmoodi tunnetada.

George Moore (1903) seadis moraalse tõe võimalikkuse kahtluse alla aga juba kolmveerand sajandit varem nn avatud küsimuse argumendiga. Tegu on tõestusega, et moraalsetel mõistetel (hea, kuri jt) puudub tähendussisu, nagu ülejäänud mõistetel (ümmargune, valge jne). Näiteks mõistet ümmargune on võimalik defineerida nii: Ümmargune on see, mille pinna kõik punktid on keskmest samal kaugusel. Teame, et definitsioon on tõene lause (st mõiste on defineeritud ammendavalt) siis, kui kas-küsimus osutub mõttetuks. Kas ümmargune on see, mille pinna kõik punktid on keskmest samal kaugusel? on sama mis küsida: Kas see, mille pinna kõik punktid on keskmest samal kaugusel, on see, mille pinna kõik punktid on keskmest samal kaugusel?

Moore (1903, 13.2) väidab, et moraalimõistetega pole nii. Näiteks mõiste hea näib olevat seotud omadusega nauditav. Seega: Hea on see, mis on nauditav. Kui aga selle põhjal koostada küsimus Kas nauditav on hea?, siis ei ole siin tegemist mõttetu küsimusega. Selle küsimuse kohta saab esitada järgmise küsimuse: Kas on hea, et nauditav on hea? Ja siin on küsimuse all juba metaeetiline probleem, kas naudingu pidamist moraalseks hüveks saab pidada moraalseks hüveks. Ja saab esitada veel järgmise mõistuspärase küsimuse Kas „Kas on hea, et nauditav on hea” on hea?, st kas on moraalne hüve 
kahelda moraalsete hüvede paikapidavuses. Selliseid pesastatud küsimusi võib esitada lõpmatuseni, ilma et need muutuks mõttetuks. Moore’i argument on küll oluliselt keerulisem, kuid tema kokkuvõte on, et moraalsete mõistete tähendussisu on defineerimatu. Ehk teiste sõnadega: moraalitõdedel puudub tähendussisu, neid ei eksisteeri.

Ometigi on moraalimõisted inimestele tähenduslikud, st tegu ei ole objektiivset maailma kirjeldavate mõistetega, nagu ümmargune või valge, vaid normatiivsete mõistetega, mille sisu põhineb sotsiaalsel kokkuleppel. Ehk teisisõnu, Moore'i avatud küsimuse argument toetab kultuurirelativistlikku maailmavaadet täpselt samamoodi kui Mackie (1977) moraali eksitusteooria.

Paradoksi süvendab asjaolu, et XX sajandi analüütiline filosoofia, täpsemalt tõe deflatsiooniteooria on esitanud mõjuvaid argumente, et tähendussisu puudub ka mõistel tõde (vt Stoljar, Damnjanovic 2014). Oletame, et meil on lause Lumi on valge. Kui lumi on valge, siis on tõene ka lause Tõsi on, et lumi on valge. Siit saab loogiliselt tuletada lause „Lumi on valge” on, et lumi on valge. Deflatsionistid teevad siit järelduse, et lause mingi väite tõesuse kohta ei lisa mitte midagi selle väite tähendusele, ehk teisisõnu, mõiste tõsi on tähendustühi, ja sealt edasi, detailidesse laskumata, et tõde kui sellist ei eksisteeri.

Samas on iseenesestmõistetav, et mõisted tõde ja vale on inimeste jaoks tähenduslikud. Selle põhjal on ainus mõistusepärane järeldus, et ka tõde ja vale on normatiivsed mõisted, millega kinnitatakse või vaidlustatakse väidete paikapidavust. Ehk tunnetuslikke, episteemilisi nähtusi hindavad mõisted tõde ja vale ning moraalimõisted hea ja kuri on samased: nad annavad hinnanguid väidetele, nähtustele või tegudele. Ei tõde, vale, hea ega kuri ole aga nende nähtuste olemuslikud omadused, mida nendega iseloomustatakse. Sellise argumentatsiooni järeldus on totaalne relativism: kõik, mida me maailma kohta teame, on normatiivne, st sotsiaalne kokkulepe, et miski on tõde või hea või kuri.

See järeldus ei tohiks tulla üllatusena kellelegi, kes on tuttav sotsiaalse konstruktivismi teooriaga (Berger, Luckmann 1967). Kuna sotsiaalne konstruktivism on hetkel üldaktsepteeritud paradigma, siis võiks ju öelda, et tuleb jätta igasugune lootus ja tunnistada tõena iga väidet, millega enamus nõus on. Sest tõde on etnotsentriline, ja seda mitte üksnes humanitaarteadustes, vaid ka loodusteadustes.

\section{Tuumväärtused ja tõde}

Tõe etnotsentrilisus tähendab, et tõde on identiteedipõhine - see kehtib mingis kultuurilises kogukonnas konsensuse põhjal. Meie praegune tõejärgne ühiskond on põhjustatud asjaolust, et suured rahvuslikud identiteedid on killustunud paljudeks väikesteks identiteedikogukondadeks, millel on välja kujunenud vähemalt osalt erinevad tõerežiimid. Nende tõerežiimide omavahelised vastuolud tulenevad asjaolust, et ükski kogukond ei ole valmis aktsepteerima tõena väiteid, mis lähevad vastuollu nende identiteedi tuumväärtustega.

Tuumväärtused on iga identiteedi jaoks keskse tähtsusega, sest neid jagab enamus rühma liikmeid. Tuumväärtused ei ole lihtsalt tunnetuslikud tõed, nagu teadmine, et maakera on ümmargune. Tavainimese seisukohalt ei ole 
erilist vahet, kas maa on lapik või ümmargune, mistõttu ei tunne enamik kerauskseid lamemaalaste vastu mingit erilist vaenu. Tuumväärtused on sellised väärtused, mille üle ei kaubelda, näiteks jumal, usk, kodumaa, emakeel, rahvus, lipp ja teised sümbolid, samuti kesksed moraaliprintsiibid (Ehala 2018). Neil on väga kaalukas emotsionaalne tähtsus rühma liikmete jaoks, need on pühad.

Tuumväärtuste kahtluse alla seadmine või mõnitamine võib esile kutsuda üsna raevuka vastureaktsiooni, mistõttu vaidlused tuumväärtuste üle on enamasti kirglikud ja leppimatud. Äärmuslikem näide on kättemaks Charlie Hebdo ajakirjanikele prohvet Muhamedi naeruvääristamise eest. Tugeva emotsionaalse laetuse tõttu pole imestada, kui tuumväärtuste muutumiseks on vaja pikemat ajaperioodi kui üks põlvkond. Näiteks kristlikes ja islamikogukondades on homoseksuaalsust peetud sajandeid patuks. See hoiak hakkas Euroopa kultuuriruumis murenema umbes 50 aastat tagasi, kuid ei ole tegelikult siiani oma tuumväärtuse positsiooni kaotanud. Põhjus on selles, et esialgu oli küsimuse all üksnes leebem suhtumine neisse, kes heteroseksuaalsest normist kõrvale kaldusid. Teravaks on vaidlus läinud viimasel ajal, kui kahtluse alla on seatud tuumväärtuseks peetav norm.

Inimene, kes ei tunnista oma rühma tuumväärtusi, riskib langeda moraalse hukkamõistu alla või kuulutatakse ta otseselt lindpriiks. Isegi kui nii ei juhtu, on enamuse väärtuste ja tõekspidamistega vastuolus elamine inimesele raske, paratamatult tunnetaks ta end siis rühmas marginaalsena, mis võib viia vabatahtliku eraldumiseni. Veendunud väärtusliberaalide ähvardused kolida Kanadasse pärast Trumpi ja EKRE võimuletulekut väljendavad sellist väärtuskonflikti ilmekalt.

Eelnevast järeldub, et kui tuumväärtuste üle läheb lahendamatuks vaidluseks, ei saa vaidlevad fraktsioonid enam ühtse rühmana eksisteerida, eriti siis, kui erimeelsusi tuumväärtustes on juba rohkem kui ühendavaid osi, nii et tundub lootusetu leida ühist keelt. Kui vastuolud on liiga suured, siis ei aktsepteerita teineteist enam sama rühma liikmena. Seega, kui tõe hegemoonia kaob, lakkab eksisteerimast ka selle tõega seotud kollektiivne identiteet kui inimesi ühiste väärtuste alusel ühendav ühiskondlik institutsioon. Nii on mis tahes ühise identiteediga rühma kestlikkuseks vajalik tõe hegemoonia vähemalt tuumväärtusi puudutavates küsimustes.

Siit tuleneb, et identiteedi ja tõe vahel valitseb paradoksaalne suhe. Ühelt poolt peaks iga kollektiivi püsimise jaoks hoidma tõe hegemooniat, teiselt poolt aga lammutab selline arusaamine tõe alustalasid - sest tõe mõiste viitab sellele, et tõde saab olla vaid üks, eri identiteetide olemasolu aga viitab, et tõde ei ole kunagi üks. Kultuurirelativism ja postmodernism on üks võimalik lahendus sellele paradoksile - tõed ongi erinevad. Selle lahenduse hinnaks on aga tõdemus, et tõde ei eksisteerigi, isegi mitte loodusteadustes.

Olukord on küll hull, aga siiski mitte lootusetu. Asjaolu, et mitte üksnes moraalitõed, vaid ka tõed maailma kohta põhinevad konsensusel, pakub ka lahendustee.

Inimesel puudub võimalus maailma kirjeldada teisiti kui keele vahendusel ja tunnetada teisiti kui oma meelte kaudu. See tähendab, et iga seletus on vahendatud ja väljendab üksnes meie hetke parimat arusaamist maailma kohta. Missugune maailm tegelikult on, seda me ei tea, aga oma mõõteriistu 
täiustades ning üha rikkalikumat ja paremat andmematerjali analüüsides võime loota, et meie ettekujutus maailmast muutub aina täpsemaks.

Loodusteadustes on tõe kriteeriumiks olnud praktika: kui mingi teaduslik avastus on võimaldanud maailmas paremini hakkama saada, siis on selle eitajad aja jooksul konkurentsis teiste kultuuridega kaotajaks jäänud. Hea näide on, kuidas heliotsentriline maailmapilt kummutas geotsentrilise ja ühes sellega kõigutas religioosseid tõekspidamisi maailma loomisest, st viis ka tuumväärtuste ümberhindamisele. Kergelt see ei tulnud, aga siiski on loodusteadustes senised suured vaidlused lõppenud tõe hegemoonia taaskehtestamisega.

Kuna niihästi tõde maailma kohta kui ka moraalseid väärtusi puudutavad tõed (identiteedi tuumväärtused) on sotsiaalselt konstrueeritud, siis tuleks eeldada, et iga kultuuri enda huvides on omaks võtta sellised tuumväärtused, mis aitavad maailmas paremini hakkama saada. Need moraalitõed, mis võimaldavad ühiskonnal paremini hakkama saada, väljendavad täpsemalt seni veel lõpuni tunnetamata tõde inimeseks olemise kohta, samamoodi nagu need tõed maailma kohta, mis aitavad ühiskonnal paremini hakkama saada, väljendavad täpsemalt maailma seni veel lõpuni tunnetamata olemust.

\section{Jumalik tõde}

Ülaltoodud väljapääs relativismist eeldab usku, et inimlike tõdede kõrval on olemas ka jumalik tõde, mida inimesed pole veel võimelised lõpuni tunnetama, nii et saaks ilma kahtlusteta öelda, mis on tõde. Küsimus jumalikust tõest on eksistentsiaalne niihästi teadusele kui ka moraalile. Kui eeldame, et maailm on reaalne, st üks kõigile meile, kes me selles elame, siis saab maailmal olla vaid üks tõene kirjeldus. Kui me seda ei eeldaks, poleks mõtet teadust tehagi, võiks kohe öelda, et on vaid alternatiivsed faktid. Kui inimesed on kõik üks liik, mis tunneb moraali mõistet, siis tuleks eeldada, et on olemas ka üks absoluutne moraalisüsteem, millel on vaid üks tõene kirjeldus. Ja kui see on nii, siis on kogu humanitaarteadusliku tegevuse ülim eesmärk liikuda jumaliku tõe tunnetamise suunas, nagu suured filosoofid on oma töödes ka püüdnud teha.

Kuigi see on usu küsimus, oleks väär eeldada, et mis tahes praegu tuntud teaduslik teooria on täielik maailma kirjeldus või et mõni praegu eksisteerivaist moraalisüsteemidest on moraalse absoluudi täielik kirjeldus. Sellisel juhul jääks ju vaid oodata tõese maailmavaate võitu, mis väärad moraalisüsteemid hävitab - sest kui üks on õige, siis kõik ülejäänud on vähemalt osaliselt ebamoraalsed ja õigustamatud.

Kui hoiduda sellisest fundamentalistlikust lähenemisest, samal ajal aga mitte leppida täieliku moraalse relativismiga, jääb üle uskuda, et moraalse absoluudi poole saab vaid liikuda ning see on samasugune käimasolev protsess, nagu loodusteadustes on lähenemine jumalikule tõele maailma olemuse kohta, ja et moraalne absoluut on inimese jaoks praegu lõpuni läbi tunnetamata, nii nagu on lõpuni läbi tunnetamata meid ümbritsev objektiivne reaalsus. See ei tähenda muidugi, et jumalik tõde on tunnetamatu: nii nagu inim- 
kond on õppinud sügavamalt tunnetama maailma olemust, oleme ajaloo käigus õppinud sügavamalt mõistma ka jumalikku tõde moraali vallas.

Moraalse absoluudi olemasolu on isegi hukatuslikum eitada kui objektiivse reaalsuse lõplikku, ühtset olemust. Sest kui vaidlus väärtuste üle on vaid konsensuse küsimus, siis peaksime olema valmis pidama tõeks mis tahes väärtussüsteemi, mis leiab enamuse poolehoiu. Kui eitada moraalse absoluudi olemasolu, siis mille alusel väita, et Natsi-Saksamaa väärtussüsteem, mis sündis ju täiesti demokraatlikul teel ja millel oli suure tõenäosusega enamuse toetus, on halvem kui mis tahes teine enamuse toetusega demokraatliku väärtusdiskussiooni tulemusel sündinud väärtussüsteem? Moraalse absoluudi eksisteerimise eitamine tähendaks eitada ka eri moraalisüsteemide võrdlemise võimalust, samuti moraalse arengu võimalust. Kui ei ole absoluuti, siis ei ole võimalik ka sinnapoole areneda.

Kant (1960 [1793]) on öelnud, et kui tunnistame moraalset absoluuti, siis peame tunnistama ka jumala olemasolu, sest jumal pole muud kui moraalne absoluut. Ma ei väida, et jumaliku tõena tuleks aktsepteerida pühakirjas esitatud tõdesid, olgu siis maailma olemuse või moraali kohta. Isegi kui pühakirjad on jumalik ilmutus, saab inimene jumalikku ilmutust väljendada (ja mõista) üksnes oma varasemate teadmiste ja keele poolt antud kategooriate vahendusel. Nii nagu objektiivse maailma tunnetuses sõltub jumaliku tõe mõistmine inimese varasematest teadmistest maailma kohta ja tema käsutuses olevate mõõteriistade tehnoloogilisest tasemest, sõltub moraalse absoluudi tunnetamine ühiskonna, kultuuri ja majanduse arengust. Ja sedavõrd, kuidas areneb teadus, tehnoloogia, ühiskond ja kultuur, saab võimalikuks üha täiuslikum jumaliku tõe tunnetamine niihästi objektiivse maailma kui ka moraalse absoluudi kohta. Seetõttu ei saa absoluutne olla ka ükski pühakiri kui jumalik ilmutus, sest paratamatult on iga ilmutus vahendatud konkreetse inimliku teadmise kaudu mingil konkreetsel ajahetkel. See arutluskäik, muuseas, esineb koraanis $(3.7 ; 13.39 ; 43.4)$, kuid piiblis mitte.

\section{Absoluudi otsimine}

Teaduses on tõe otsimine üks suuri eesmärke ja loodusteadusliku maailmamõistmise üha sügavamaks muutumine näitab ilmekalt progressi selles vallas. Loodusteaduste arengulugu saab seega mõista kui liikumist absoluutse tõe tunnetamise suunas, ükspuha, kas see absoluut on reaalselt saavutatav või mitte.

Humanitaarteaduslikud tõeotsingud näivad aga olevat liikunud hoopis keerulisemalt. Neis teadustes, mis tegelevad ka empiirilise materjaliga, näiteks arheoloogia, ajalugu, psühholoogia, on uute mõõtmisvahendite kasutuselevõtt või lihtsalt hea juhus toonud aja jooksul uusi andmeid, mille põhjal saab väita tõe üha täielikumat tunnetamist. Kõige pehmemais humanitaarteadustest, nagu filosoofia, pigem korduvad samad tõed eri autorite töödes eri ajastutel, erineval viisil arendatuna ja põhjendatuna. Ei ole ka mingeid tõestamis- ega kummutamismehhanisme. Vaidlus idealismi, materialismi, realismi ja nominalismi vahel on praegu sama lahendamata nagu tuhandeid aastaid tagasi. Erinevad tõed kõnetavad eri aegu, muutuvad populaarseks ja mõjutavad ühis- 
konna arengut. Mõne aja pärast aga muutuvad ebapopulaarseks, kui mõni vahepeal varjusurmas lähenemine näib ühiskonna soovidele paremini vastavat.

Küsimus teaduslikust progressist humanitaarteadustes on põhiolemuselt eetilise mõtte ja moraalisüsteemi arengu probleem. Mis tahes humanitaarteaduslikul väitel või teoorial on alati otsesed või kaudsed järelmõjud ühiskonna tuumväärtustele, humanitaarteadusliku tegevuse tulemuseks on muutused ühiskonna väärtushinnangutes ja moraalisüsteemis. Küsimus on selles, kas need muutused viivad absoluudi sügavama tunnetamise suunas või pole olemas mingit absoluuti. Ja mis järelmõjud humanitaarteadlase tööl ka ei oleks tuumväärtustele, pole üks parem teisest.

Konfutsius ja Kant jaatavad moraalse absoluudi poole liikumist (vt Xie 2012). Konfutsius kasutab mõistet junzi, mis on eesti keelde tõlgitud kui õilis inimene (Konfutsius 2009), kes käitub moraalses plaanis laitmatult, nii et teda võib võtta moraalse käitumise eeskujuna. Siit aga tekib kohe kiuslik küsimus, milline on moraalselt laitmatu inimene, kui moraalireeglid erinevad kultuuriti. See küsimus on iseäranis aktuaalne praegusel kultuurilise mitmekesisuse ajastul. Dilemma tekitab hinnangu andmine erinevatest moraaliõpetustest lähtuvale käitumisele, st erinevate etnotsentristlike tõdede võrdlemine. Kui lähtuda oma kultuuri moraalinormidest, siis tuleks hukka mõista mõne teise kultuuri tõed, mis on nende normidega vastuolus. Samamoodi mõistavad teised hukka sinu kultuuri moraalinormidest tuleneva käitumise, kui see läheb vastuollu nende normidega. Kui eri kultuurid omavahel üldse kokku ei puutu, probleemi ei ole, kuid samas ühiskonnas toimides tuleks hinnangut andes paratamatult seada kahtluse alla teise rühma tuumväärtused. Konflikti vältimiseks oleks kõige targem hinnangut mitte anda. Selline käitumine aga ei saa olla jätkusuutlik, sest loob eelduse ühiskonna kui ühiste tuumväärtuste ja identiteediga rühma lagunemiseks (vt põhjalikumat analüüsi Ehala 2016).

Konfutsiuse klassikaline töö „Keskmine tavaline” (vt Konfutsius 2009) pakub sedalaadi dilemmale lahenduse, eristades kaht tüüpi moraalseid tõdesid. Jumalik tõde on inimesele määratud Taeva (Tian) poolt ja selle suunas areneb kogu elu, et lõpuks saavutada harmoonia Taevaga. Teine tüüp moraalseid tõdesid on väljendatud moraalireeglites, mis püüdlevad selle poole, et võimalikult täpselt sõnastada Taeva poolt antud moraalset absoluuti, st jumalikku tõde. Paraku ei pruugi inimeste sõnastatu olla kooskõlas jumaliku tõega, st on alati võimalus, et olemasolevad moraalireeglid on ekslikud. Konfutsiuse kohaselt on junzi sellisest moraalsete tõdede kahetisest iseloomust teadlik ja otsib teed, kuidas oma käitumises vähendada vastuolu moraalse absoluudi ja igapäevaste moraalireeglite vahel. Tavaline inimene (xiaoren) aga seda vahet ei mõista, vaid lähtub üksnes moraalireeglites sõnastatud tõdedest. Tavalise inimese jaoks ei ole olemas moraalset arengut, vaid üksnes reeglitele kuuletumine, ükskõik millised need ka parasjagu poleks.

Sama dilemma üle arutleb ka Kant (1960 [1793]), kelle kohaselt inimese vaba tahe võimaldab valida hea ja kurja vahel, ja oma valikut tehes inimene ka vastutab selle eest. Kant eristab kolme liiki kurjust. Esiteks kuri, mis tuleneb sellest, et inimene lihtsalt ei järgi kehtestatud moraalireegleid, st valib teadlikult kurja. Sellise käitumise mõistab ühiskond hukka ja inimene ise peaks tundma süümepiinu, kui ta käitub reeglite vastu, millesse ta ise usub. 
Teine liik kurja tuleneb sellest, et inimene käitub küll moraalireeglite järgi, kuid tema käitumise motiivid pole moraalsed. Sellise käitumise heaks näiteks on Eesti poliitikaski tuntud JOKK skeemid. Kolmas sort kurja tuleneb sellest, et kehtestatud moraalireeglid on iseenesest vastuolus moraalse absoluudiga, nii et mida paremini inimesed neid reegleid järgivad, seda rohkem kurja nad teevad. Seda tüüpi kutsub Kant radikaalseks kurjuseks.

Kanti kohaselt on vabal tahtel loomulik kalduvus hea suunas, seega on ebamoraalsete reeglite kehtestamine juba iseenesest ebamoraalne tegu, kuna läheb vastuollu vaba tahte loomuliku kalduvusega. Iga ebamoraalset reeglit järgiv tegu on omakorda ebamoraalne, sest on vastuolus vaba tahte soodumusega teha head. Nii teeb ka Kant vahet moraalsel absoluudil, mille poole vaba tahtega inimene pürgib, ja kehtival moraalisüsteemil, mis peaks vaba tahte loomulikust kalduvusest lähtudes püüdlema absoluudi poole, võib aga siiski eksliku moraaliloome tagajärjel võtta radikaalse kurjuse vormi.

Kuigi Kant ei anna vastust, miks inimesed valivad radikaalse kurjuse, kui nende loomus peaks püüdlema headusele, on ta siiski konkreetne selles, et inimene peaks loobuma ebamoraalsetest reeglitest, st tegema selliseid moraalseid valikuid, et radikaalset kurjust vähendada. Niisiis on ka Kanti õpetuses idee moraali kahetisest olemusest ja põhimõte, et moraalne inimene peaks oma käitumisega püüdlema maailmas radikaalse kurjuse vähendamise poole. Wenyu Xie (2012) jõuab järeldusele, et nii Konfutsiuse kui ka Kanti õpetuses esineb idee moraalsest evolutsioonist, pidevast lähenemisest moraalsele absoluudile (ja lisab, et Kant võis olla Konfutsiusest mõjutatud).

Kui tulla tagasi teesi juurde, et moraalne tõde (hea, kuri) ja tunnetuslik tõde (tõene, vä̈̈r) on oma olemuselt samased - kokkuleppelised -, siis ei erine Konfutsiuse ja Kanti moraalse tõe otsingud loodusteadusliku tõe otsingutest: mõlemad on suunatud üha täiuslikumale tõe tunnetamisele. Tõe otsing on aga individuaalne ja kui inimene oma otsingu tulemused avalikustab, võib tekkida väitlus tuumväärtuste üle. Ja võib tekkida uus moraalisüsteem või vähemalt alus muutuste tegemiseks.

Nüüd tekib küsimus, mille poolest Konfutsiuse ja Kanti arusaam erineb meie praegusest arusaamast, et moraalinormide üle arutlemine on ühiskondliku elu loomulik osa - ühiskond vaidleb ja kui üks idee saavutab hegemoonia, kujuneb see uueks tõeks, mis mõne aja pärast asendub uue tõega. Erinevus on eelduses: Konfutsius ja Kant eeldavad, et eksisteerib moraalne absoluut, jumalik tõde, mille suunas peaks viima väitlus moraali üle. Kui seda mitte eeldada, nagu tänapäeva vaidlustes, siis tähendab, et pole olemas ka radikaalse kurjuse mõistet, sest ükski moraalisüsteem, mis põhineb enamuse hegemoonial, ei saa olla ebamoraalne.

Samas tunnistab Kant, et ühiskonnad võivad valida radikaalse kurjuse lihtsalt eksituse tagajärjel. See tähendab, et moraalsetes otsingutes püüeldakse absoluudi poole, kuid ei olda võimelised seda tunnetama või pigem saadakse sellest valesti aru ning valearusaamise tulemusel kehtestatakse ebamoraalsed reeglid, mis suurendavad radikaalset kurjust. Selle probleemi lahenduse võtmeküsimus on see, kuidas vahet teha, millised reeglid viivad lähemale moraalsele absoluudile ja millised tulenevad radikaalsest kurjusest.

Kant ja Konfutsius väidavad, et inimene/junzi suudab jumalikku tõde intuitiivselt tunnetada ja sellest lähtuvalt oma käitumist sättida. Samal 
eeldusel põhinevad ka pühakirjad. Kui moraalse absoluudi tunnetamine on üksnes intuitiivne, jätab see arutelu moraalsete tõdede üle irratsionaalseks, st ei ole olemas mõistuspäraseid argumente selle kohta, kas homod tuleb kividega surnuks loopida või neil tuleb lubada abielluda ja lapsi saada. Kõik sõltub moraalse absoluudi sisu intuitiivsest mõistmisest.

\section{Praktika kui tõe kriteerium}

Eeldada, et moraalse absoluudi üle on võimatu teha muid kui intuitiivseid otsuseid, on praktika seisukohalt sama hea kui väita, et moraalset absoluuti ei ole olemas, sest eri prohvetite vastandlike intuitiivsete otsuste vahel pole võimalik ratsionaalselt valida. See on ebasoovitav seisukoht, sest õigustab moraalset relativismi. Probleemi lahendamiseks oleks vaja raamistikku, mille alusel saaks eri moraalisüsteeme empiiriliselt ja ratsionaalsete argumentidega võrrelda nagu loodusteadustes. Sellise raamistiku pakkumine on humanitaarteaduste ülesanne. Praegused humanitaarteadlased on aga tõstnud käed üles ja väidavad, et sellist raamistikku pole mõtet otsida, sest kõik tõed on etnotsentristlikud ja mingit jumalikku tõde pole olemas.

Sellest on vaid üks väljapääs: tunnistada, et eksisteerib üks jumalik tõde ja kogu teadusliku tegevuse eesmärk nii loodusteadustes kui ka humanitaarias on liikuda selle üha täielikuma tunnetamise suunas. Seda tunnistada tähendab ühtlasi tunnistada, et olemasolul on mõte ja et evolutsioon liigub madalamatelt eluvormidelt kõrgematele, üha sügavama tegelikkuse, iseenda ja absoluudi tunnetamise suunas.

Seda eeldust kinnitab maailma senine arengukäik. Kui kogu evolutsiooni ja olemasolu mõte on liikuda järjest sügavama absoluudi tunnetamise suunas, siis järelikult ei saa moraalne olla midagi sellist, mille tagajärjel katkeb ühiskonna või laiemalt inimkonna areng absoluudi tunnetamise suunas. Näiteks kui üks maailma arvukatest kultuuridest on oma arust jõudnud väga lähedale absoluudi tunnetamisele, kehtestades reegli, et inimene ei tohi looduskeskkonda mõjutada, ning enamus ühiskonnaliikmeid ka käitub selle reegli järgi, siis pole kahtlust, et selline kultuur sureb nälga, ja mainitud moraalireegel ühes temaga. Või siis lihtsalt loobutakse sellest reeglist. Järelikult oli tegu moraalse arengu tupikteega, eksimisega absoluudi tunnetamisel.

Eelneva arutluse põhjal on alust arvata, et maailma ajalugu praagib välja arengud, mis viivad kaugemale moraalsest absoluudist. Täpsemalt väljendudes: identiteedid, mis on võtnud omaks radikaalsest kurjusest lähtuvad moraalireeglid või terve moraalisüsteemi, hääbuvad, lagunevad või on sunnitud oma printsiipe muutma, kui taibatakse, et samamoodi edasi ei saa. Kui see on nii, siis on ühiskonna kestlikkus moraaliprintsiipide võrdlemisel oluline kriteerium: kui moraalireeglid tagavad ühiskonna kestlikkuse, on tegu jumaliku tõe hea üldistusega, kui aga ühiskond ei suuda oma kestlikkust tagada, siis on radikaalne kurjus juhtinud ühiskonna õigelt teelt kõrvale.

Olgu toodud kaks läbikukkumise näidet erinevat tüüpi radikaalse kurjuse kohta. Kui ühiskond püüab oma jätkusuutlikkust tagada vägivalla kaudu teiste rühmade vastu, näiteks nagu tegi Natsi-Saksamaa, ja kehtestab moraalireeglid, mis õigustavad vägivalda ja vägivallatsevat vähemust, 
siis sellise süsteemi lagunemise eeldused tulenevad asjaolust, et vähemus ei suuda enamust lõputult alla suruda. Mis tahes tugevama õigusel põhinev moraalisüsteem ei ole kestlik, sest mingil hetkel tekib „nõrkade” koalitsioon, mis selle moraalisüsteemi kukutab. Kui ühiskond püüab aga oma jätkusuutlikkust tagada selliste moraalireeglitega, mis keelavad igasuguse vägivalla teise inimese vastu, siis on seegi süsteem jätkusuutmatu, sest eitab ka nende karistamist, kes vägivalla keelust üle astuvad ja teiste kallal vägivalda tarvitavad.

Need kaks näidet on äärmuslikud ja tänu sellele on kerge näha nende negatiivset mõju kestlikkusele. Kuid vaid vähesed moraaliprintsiibid on nii absoluutsed ning positiivset või negatiivset mõju ei ole kerge hoomata, kas või seetõttu, et tänapäeva ühiskonnad on rahvarohked ja ressursirikkad ning võib võtta põlvkondi aega, kuni ühe või teise radikaalsest kurjusest lähtuva moraalireegli negatiivsed tagasilöögid ilmseks saavad. Näiteks võttis 70 aastat, enne kui kommunistliku moraalisüsteemi jätkusuutmatus tuli ilmsiks. Eelneva arutelu eesmärk oli näidata, et tõe kriteerium moraalisüsteemide hindamisel on praktika: eksimuste analüüsi põhjal on võimalik jõuda üha lähemale moraalse absoluudi tunnetamisele.

Eksimuste analüüsi teeb aga keeruliseks see, et kultuuride jätkusuutlikkus ei sõltu ainult moraalisüsteemist, vaid ka väliskeskkonnast - ressursside kättesaadavusest, vaenulike naabrite või tõbede olemasolust -, mistõttu on raske üheselt määratleda, kas kultuur lakkas olemast väliskeskkonna vaenulikkuse, ühiskonnasisese radikaalse kurjuse või mõlema toimel. Nähtustevahelised põhjuslikud seosed ei ole alati ühesed ega kergesti mõistetavad. Muistsetes kultuurides oli põhjuslikke seoseid võib-olla lihtsam näha, sest halbade moraalireeglite tagajärjed ilmnesid suhteliselt ruttu, kuna kogukonnad olid väikesed. Vanas Testamendis ja koraanis põhjendatakse kehtestatud moraalireegleid korduvalt vanade linnade varemetega, hoiatades, et siin oli ühiskond, mis lakkas olemast, sest ei järginud jumala käsku ja jumal karistas neid selle eest. Või et selle maailma vägevad kaotasid oma au ja hiilguse kurja tõttu, mida nad korda saatsid.

Mida sellest kõigest järeldada? Et elu sunnib meid kurja tegema? Jah, selleks et elada, peame hävitama muud elu. Kant (1960 [1793]) küll ütleb, et paratamatu hävitamine pole kuritegu, kuid absoluutsest vaatenurgast ikkagi on. Kui peame elu paratamatuseks, siis paratamatult tuleb ka kurja teha. Moraalset arengut sellisest paratamatusest lähtuvalt vaadates on jätkusuutlik selline ühiskond, kus hea ja kurja tegemise vahekord on optimaalselt tasakaalus, arvestades teaduslikku ja tehnoloogilist arengutaset. Sedavõrd, kuidas tehnoloogia areneb, muutuvad ühiskonnad oma kestlikkuse tagamisel vilunumaks, nii et on võimalik teha vähem kurja kui varem. Ja kui taibatakse, et süsteemi jätkusuutlikkus on tagatud ka vähema kurjaga, siis kehtestub uus süsteem, mis on lähemal absoluudile. Peame lihtsalt suutma ära tunda, et kui üritame moraalisüsteemi muutmisega kurja vähendada, ei vähendaks me seda niipalju, et peaksime uue moraalisüsteemi jõustamiseks tegema rohkem kurja, kui seda vähendada suudaksime siis, kui ühiskond selle uue moraalisüsteemi on lõpuks omaks võtnud. Ühiskond, kes peab mingi moraalireegli kehtimise jaoks represseerima rohkem üleastujaid, kui selle reegli järgimisega suudetakse kellelegi heaolu luua, ei saa olla jätkusuutlik. 
Eelnev pakub kategoorilise imperatiivi humanitaarteaduste metodoloogiale: kuigi ühiskonnad ja kultuurid on väga erinevad, osalt keskkonnatingimustest, osalt tehnoloogiate ja teadmiste erinevusest ja osalt kindlasti ka vabast varieerumisest tulenevalt, on nende erinevuste uurimise ja mõtestamise kaudu võimalik mõista fundamentaalseid ja universaalseid inimeseks olemise põhimõtteid. See on kogu humanitaarteadusliku (ja laiemalt kogu teadusliku) tegevuse põhieesmärk, isegi kui konkreetsed uurimisülesanded on kitsad ega ole otseselt selle küsimusega seotud. Pädevaid järeldusi saaks teha vaid väga suuremahuliste võrdlevate uuringutega, mis suudaks välja praakida sellised väärtused ja moraalinormid, mis on paljudes eri keskkondades viinud negatiivsete tagajärgedeni. See tundub küll olevat Heraklesele sobiv ülesanne, kuid tuleks siiski loota, et meie töö tulemusel loodud teadusliku teadmise kasv võimaldab mingil hetkel kuskil kellelgi sõnastada midagi, mis aitab kõiki absoluudi tunnetamise teel jälle veidi edasi.

\section{Kirjandus}

Aria s-Mald on ad o, Manuel Jesus 2018. A genealogy of post-truth: philosophy, affects, technology. Käsikiri. https://riuma.uma.es/xmlui/handle/10630/16392 (2. V 2019).

B erger, Peter L., Lu ckm an n, Thomas 1967. The Social Construction of Reality: A Treatise in the Sociology of Knowledge. Harmondsworth: Penguin Books.

E h a la, Martin 2016. Liberaalse multikulturalismi paradoks. - Vikerkaar, nr 4-5, lk 96-105.

Ehala, Martin 2018. Identiteedimärgid. Ühtekuuluvuse anatoomia. Tallinn: Künnimees.

Kant, Immanuel 1960 [1793]. Religion within the Limits of Reason Alone. New York: Harper \& Brothers.

Konfutsius 2009. Vesteid ja vestlusi. Keskmine tavaline. Suur õpetus. (Hiina mõttevaramu 1.) Koostanud, tõlkinud, kommenteerinud ja eessõna kirjutanud Linnart Mäll. Tartu: Lux Orientis.

Lyotard, Jean-François 1984 [1979]. The Postmodern Condition: A Report on Knowledge. Kd 10. Manchester: Manchester University Press.

Mackie, John 1977. Ethics: Inventing Right and Wrong. New York: Penguin Books.

M o o r e, George Edward 1903. Principia ethica. Cambridge: Cambridge University Press.

P op per, Karl 1959. The Logic of Scientific Discovery. London: Routledge.

Stoljar, Daniel, Damnjan ovic, Nic 2014. The deflationary theory of truth. The Stanford Encyclopedia of Philosophy. Toim Edward N. Zalta. https://plato. stanford.edu/archives/fall2014/entries/truth-deflationary/ (10. VII 2019).

Wittgenstein, Ludwig 2005 [1953]. Filosoofilised uurimused. (Avatud Eesti raamat.) Tlk Andres Luure. Tartu: Ilmamaa.

Xi e, Wenyu 2012. Kant's Better Man and the Confucian Junzi. - Journal of Frontiers of Philosophy in China, kd 7, nr 3, lk 481-497. 
Martin Ehala (snd 1963), Tartu Ülikooli emakeeleõpetuse professor, keelesotsioloogia vanemteadur (Ülikooli 18, 50090 Tartu); Helsingi ülikooli eesti keele külalisprofessor, ehalam@gmail.com

\section{Truth, identity and the moral absolute}

Keywords: social constructivism, core values, ethnocentric truth, perception of moral truths, absolute truth

The article analyses the mutual relationship of truth and identity in the context of the crumbling hegemony of truth, and its ramifications for the humanities. The author highlights the difference between the physical and humanitarian scientific truths, which during the past hundred years or more has led to serious scepticism about truth. Regarding truth as a social construct one has to admit that any truth is bound to identity: Truth is ethnocentric as it is based on the consensus of a community or a cultural group. Yet, although the hegemony of truth is important for the sustainability of collective identity, there also appears to be an assumption of its relativity, as far as different identities rest on different core values. If we accept that truth is identity-based, we also have to accept the use of "alternative facts" and the decay of truth hegemony. The hegemony of truth is based on the assumption that there is a single absolute (divine) truth about the essence of the world as well as humanness, even though that truth has never been fully apprehended. Even a true belief in the existence of such an absolute leaves open the question of its apprehension. Both Confucius and Kant refer to intuition, yet the question remains how to compare and evaluate the fruits of different intuitions. The results of humanities research have a direct impact on core values, which can (and often has) led to changes in moral systems. The final part of the article seeks an answer to the question whether it is possible to conceive a method to evaluate the truthfulness of the truths defined by humanities, first and foremost of arguments concerning values and moral norms, that is to check the conformity of those arguments to a moral absolute.

Martin Ehala (b. 1963), University of Tartu, Institute of Estonian and General Linguistics, Professor of Literacy Education (Ülikooli 18, 50090 Tartu); University of Helsinki, Visiting Professor of Estonian, ehalam@gmail.com 